\title{
三重における岩相と斜面破壊形態の特徵 \\ The characteristics of rock types and slope failures in Mie prefecture, Japan
}

\author{
相澤泰造 ${ }^{\mathrm{a})}{ }^{*} \cdot$ 酒井俊典 $^{\mathrm{b})} \cdot$ 林 拙郎 ${ }^{\mathrm{b})}$
}

Taizo AIZAWA, Toshinori SAKAI and Setsuo HAYASHI

\begin{abstract}
This paper examined typical examples of slope failures that occurred during the past 15 years in Mie prefecture, clarifying the features of slope failures controlled by geology. Sedimentary rocks and schists have been subjected to landslide with planar sliding surfaces parallel to their foliations. On their anaclinal slopes, toppling has occurred. Igneous rocks have been subjected to destructive slope failures, if they are severely weathered or fractured with adversely oriented joints. Decomposed granite in the Ryoke Belt has been subjected to compound slide. Large rockfalls and slope failures may occur in granite porphyry of the Kumano acidic rocks, in which columnar joints are developed. Weakly consolidated lake deposits have been subjected to landslide with low angle sliding surfaces parallel to the bedding plane.

Key words : Metamorphic belt, Creep, Landslide, Slope failure, Rock fall

\section{和文要旨}

本論文は，岩相と斜面の変形や破壊形態の特徵を三重県の事例について過去約 15 年にわたる事例をもとに明らかにした。堆積岩 と結晶片岩は層理面や片理面を主なすべり面とし，複合すべり，平面すべり，〈さびすべりを発生する場合が多いことが判明した。 また，受け盤の斜面，法面ではトップリングを発生する場合があることが分かった。火成岩は風化の程度や節理面の発達により破 壊形態に特徵があることが明らかになった。領家帯の花崗岩類は風化しマサ化すると複合すべりを発生する場合が多いことが明ら かとなった。熊野酸性岩類の花崗斑岩は柱状節理をなす部分では大規模落石やブロック崩壊を発生する場合があることが判明した。 低固結の湖沼堆積層では緩勾配の層理面でも複合すべりを発生する場合があることが明らかになった。このように，三重で過去に 発生した斜面の変形や破壊の形態は岩相ごとに特徵が見られることが判明した。

キーワード：地質帯，クリープ，地すべり，崩壊，落石
\end{abstract}

\section{1. はじめに}

三重はほぼ中央を中央構造線が東西に横断し，西南日 本外带・内带に分布する代表的な地質带が分布する。こ こで発生する変形や斜面破壊形態は，それぞれの地質带 ごとに分布する岩相と地質構造に規制され，特徴が異な る。

斜面破壊形態について，谷口（1965）は運動様式から 円弧すべり (slide), 平面すべり (glide), 匍行すべり (creep）の 3 種類に分類した。その後, 渡（1986）は山 腹斜面が重力により変形するクリープの考えを提唱した。 さらに, 奥園ら（1994）は過去の斜面破壊事例を整理し, 落石，ブロック崩壊，円弧すべり崩壊，たわみ性トップ リング崩壊，ブロックトップリング崩壊，バックリング 崩壊, 平面すべり崩壊, くさびすべり崩壊, 複合すべり 崩壊の 9 種類に細分化した斜面破壊形態を提示した。

藤田・板垣（1976）によると，全国で発生した地すべ りの内，堆積岩では70\%が流れ盤の層理面で発生してお り, 変成岩でも $77 \%$ が流れ盤構造で発生していた。しか し，さらに細分化された岩相と斜面破壊形態との関係に ついて論じたものは少なかった。このため, 三重を模式 地とし，そこに分布する主な岩相と過去約15年にわたっ て筆者が調查した斜面破壊形態の特徵から，岩相と斜面

* 連絡著者/corresponding author

a) 三重大学生物资源学部

Faculty of Bioresources, Mie University

Faculty of Bioresources, Mie University
$\mathbf{T} 514-8507$ 三重県津市栗真町屋町1577

1577 Kurimamachiya-cho Tu city Mie pref. JAPAN

b) 三重大学大学院生物资源学研究科

Graduate School of Bioresources, Mie University
の変形や破壊形態との関係について検討することを試み た。

本研究では図 - 1 に示すように奥園らの分類である 9 種類の斜面破壊現象を落下現象・崩れ現象・すべり現象 に区分するとともに，斜面の変形現象であるクリープ・ 膨張を加え11種類に細分し，岩相との関倸を検討した。 なお，本論文ではたわみ性トップリングを含め，崩壊に 至らない斜面の下方へのゆっくりとした変形をクリープ と呼んだ。

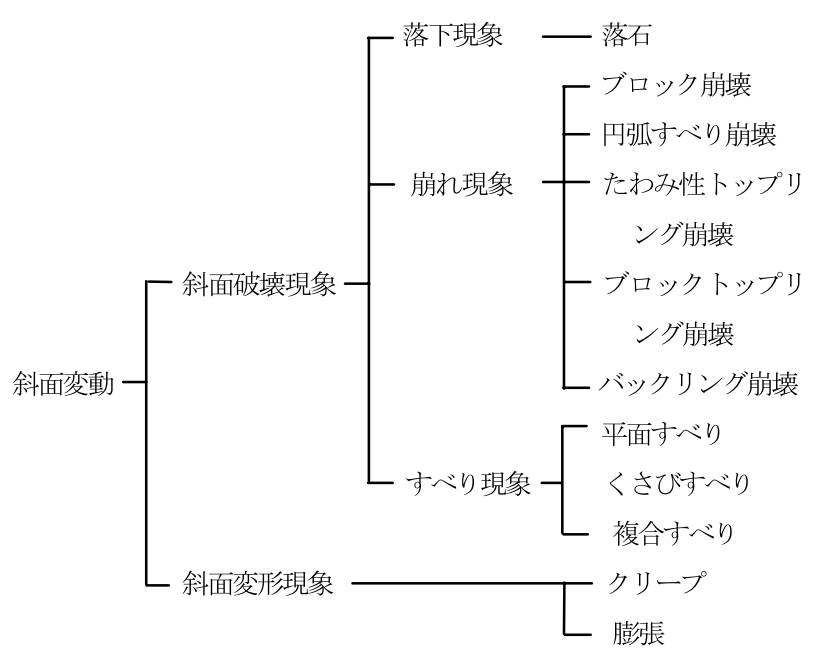

図-1 斜面変動分類

Fig. 1 The classification of slope movement. 


\section{2. 三重の地質}

三重の地質は図- 2 に示すごとく，ほぼ中央を東西に 貫く中央構造線により，南側の西南日本外帯と北側の西 南日本内帯に大別される。外带は北から, 三波川带, 秩 父带，四万十帯の付加体堆積物，および付加体堆積物起 源の変成岩がほぼ東西方向に带状をなして分布している。 なお，本研究では御荷鎍帯も三波川帯の一部に含まれる ものとした。また，三重の南西端では四万十帯に貫入し た熊野酸性岩類が分布する。熊野酸性岩類の周辺には第
三系中新統の熊野層が分布している。内帯は帯状の構造 は見られないが，南に領家帯，北端に美濃帯が分布して いる。西端には第三紀中新世の火砕岩である室生火山岩 類が分布している。鈴鹿〜松阪の中勢地区の丘陵地には 第三紀中新世の堆積物である鈴鹿層群，一志層群が分布 している。伊賀地方と伊勢湾沿いには第三紀鮮新世〜第 四紀更新世の湖沼堆積物である, 古琵琶湖層群と東海(奄 芸) 層群が分布している。

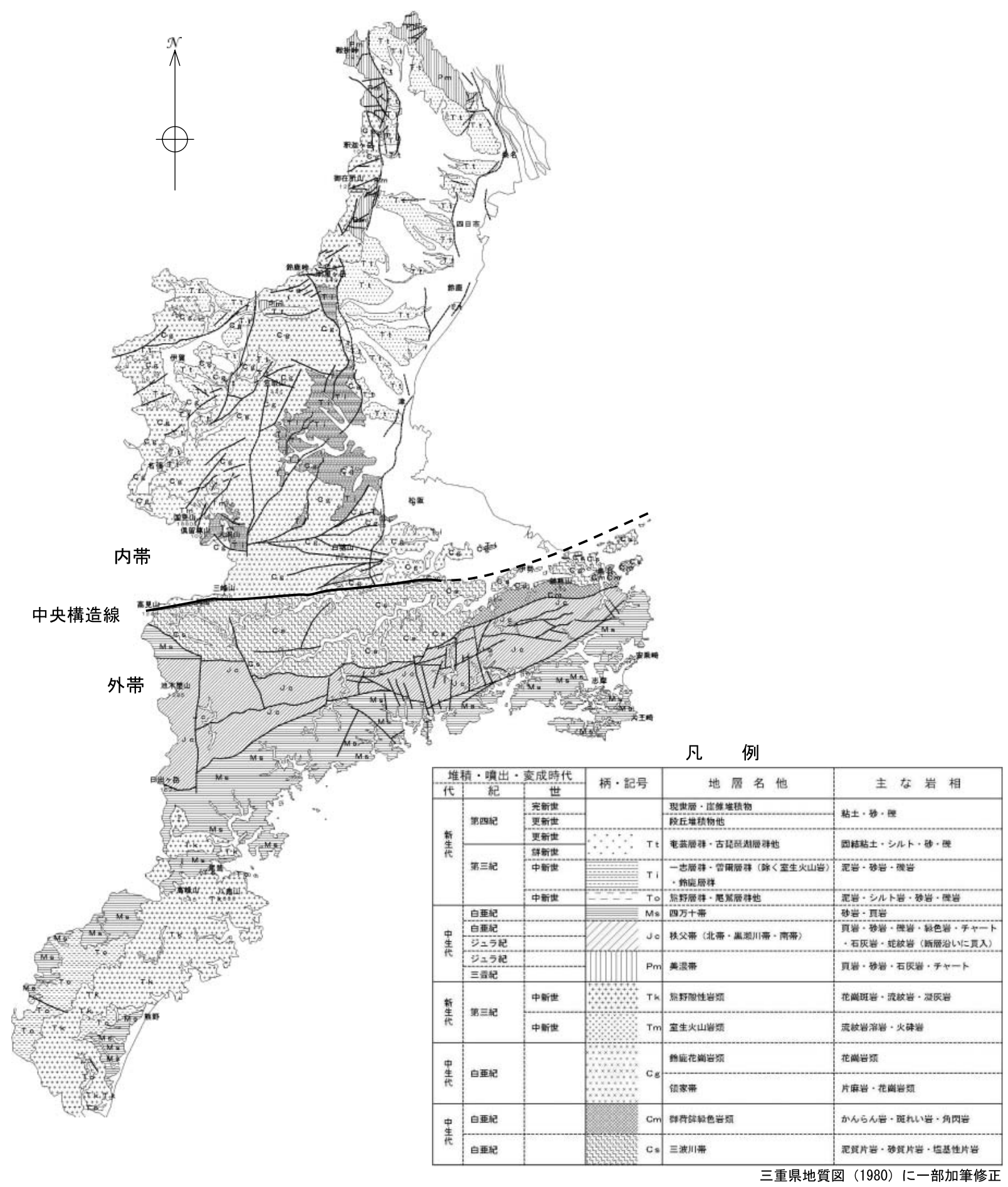

図一 2 三重県地質図

Fig. 2 Geological map of Mie prefecture. 


\section{3. 地質帯と斜面破壊の特徴}

\section{1 三波川帯の斜面破壊}

三波川带の結晶片岩は泥質片岩・砂質片岩・塩基性片 岩などからなる。三波川帯の結晶片岩はほぼ東一西の走 向を持ち，南に傾斜した片理面を持つものが多い。この 中でも泥質片岩は片理面から分離しやすいため，片理面 に対し流れ盤となっている斜面・法面では地すべりが発 生しやすい。図-3 は鳥羽市で発生した泥質片岩の平面 すべり模式図であるが，三重に分布する三波川帯の結晶 片岩を基盤とする地区で発生する地すべりは切土直後, 片理面に規制され，平面すべりやくさびすべりとなるも のが多い。これらは法肩に頭部滑落崖や引張り亀裂を発 生することが多く，切土時の応力開放に伴う膨張・緩み が地すべり発生の誘因となっているものと考えられる。 写真 -1 は図 -3 と同箇所で，切土直後に発生した典型 的な平面すべりである。三重で発生した三波川帯におけ る地すべりでは，四国で見られるような大規模な地すべ りとなる例は確認していない。2004年の21号台風では, 流れ盤をなし泥質片岩を主体とする南向き斜面において 天ヶ瀬・領内の 2 地区で地すべりが発生したが，北向き 斜面では地すべりは発生しなかった。この内，規模の大 きかった天ヶ瀬地区は幅約100m，長さ約150m，最大厚

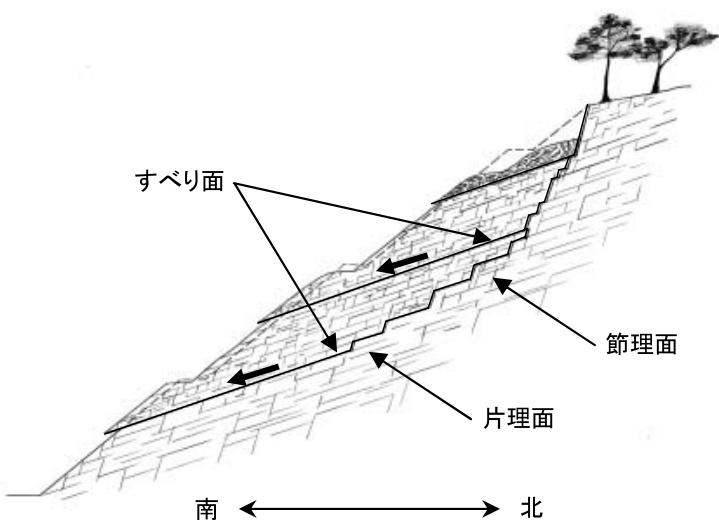

図一 3 三波川帯結晶片岩平面すべり模式図

Fig. 3 Schematic sketch showing the slide with a planar sliding surface in the Sambagawa Belt.

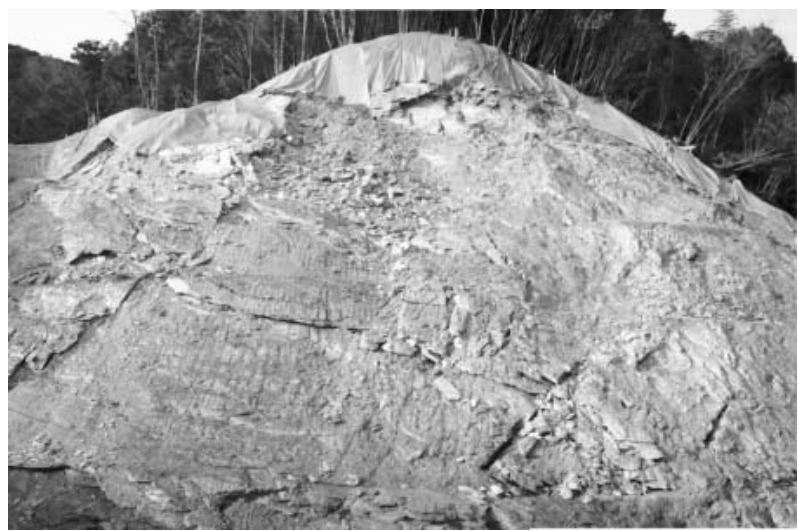

写真－1 三波川帯結晶片岩平面すべり（1992年）

Photo 1 Plain slide in the Sambagawa Belt. (1992)

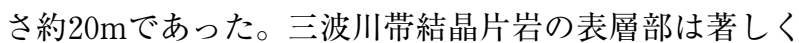
風化し，DL級岩盤と残積土が混在している場合があり， このような場所では片理面の方向に関係なく，豪雨時崩 壊することが多い。2004年の21号台風では南向き・北向 き斜面とも幅 $30 \mathrm{~m}$ 程度以下の崩壊が多数発生した。この 発生は大台町唐櫃・領内など, 特に時間最大降水量が100 mmを超えた地域での発生多かった。片理面に対し，受 け盤となっている斜面・法面では，自然状態や切土後， 山体クリープが発生することがある。この山体クリープ はCM級以下の岩盤が，表層数メートル以浅で発生する 場合が多く，クリープした法面を放置すると，クリープ の境界面と断層面などからくさびすべりに移行する場合 があることが明らかとなった。写真 - 2 は切土後約 1 年 経過した時点で発生した法面のクリープ事例であり，法 面表層 $2 \mathrm{~m} \sim 3 \mathrm{~m}$ のD〜CL級泥質片岩がクリープしたた め小段法肩のコンクリートとの間で開口亀裂が発生した ものである。写真 -3 は厚さ $2 \mathrm{~m} \sim 3 \mathrm{~m}$ の範囲において, $\mathrm{CM}$ 級泥質片岩が切土後約 5 年でクリープからくさびす べりに移行した法面破壊の事例である。本地すべりの周 辺ではほとんどクリープは認められず，同じ経年でもク リープが進行しやすい場所としにくい場所があることが
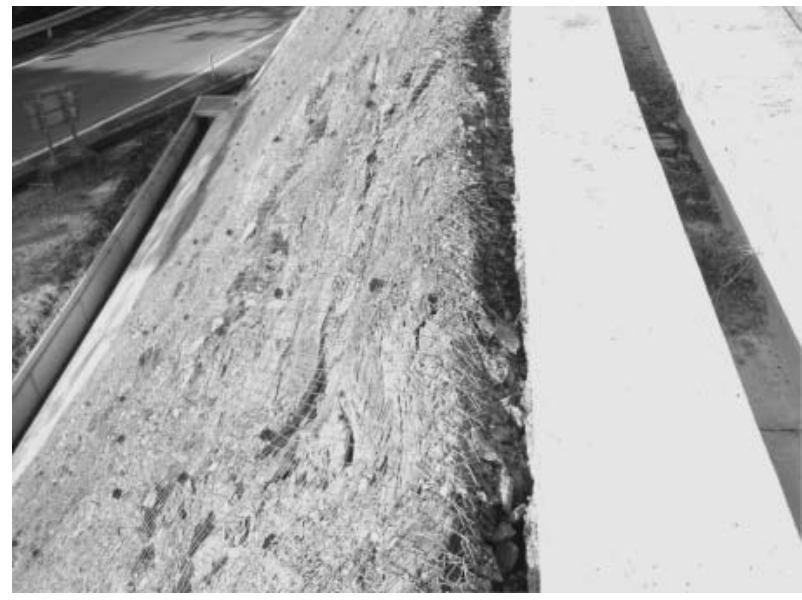

写真ー 2 クリープによる法肩の開口亀裂（2007年） Photo 2 Open cracks by creep. (2007)

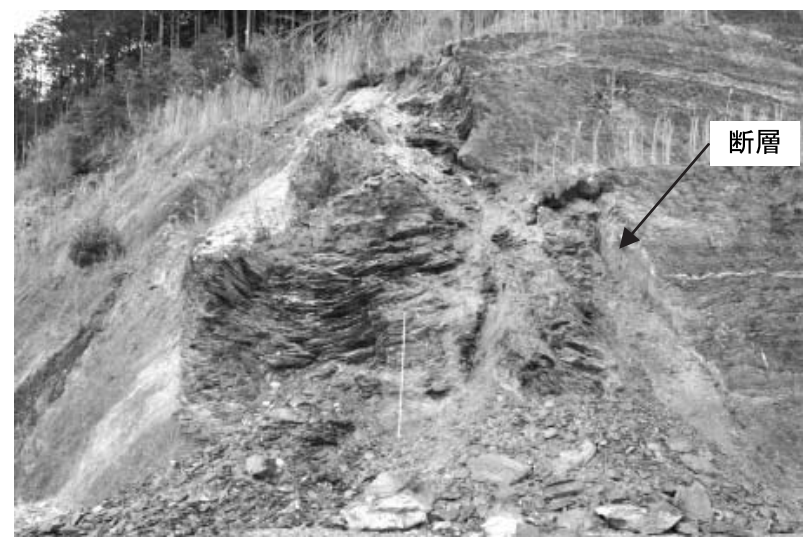

写真ー 3 クリープから移行したくさびすべり（2007年）

Photo 3 Wedge slide developed from creep. (2007) 
明らかとなった。また，クリープからくさびすべりに移 行した箇所は，写真の右側部が断層により規制されてお り，断層がクリープ発生の一因となったものと考えられ る。

\section{2 秩父帯の斜面破壊}

秩父帯はジュラ紀〜白亜紀の付加体堆積物で, 砂岩・ 泥岩などの砕屑岩からなる整然相と，砂岩・チャートな どを含むメランジェ相からなる。秩父帯は三波川帯の南 に帯状に分布し，層理面はほぼ東一西の走向を持ち北傾 斜のものが多い。流れ盤をなす斜面では，層理面を主な すべり面とする複合すべりを発生する場合がある。図一 4 は紀北町水吞峠近傍で発生した，流れ盤をなす砂岩・ 泥岩互の複合すべり模式図である。これに対し，受け盤 をなす南向き斜面ではクリープを素因とする崩壊が発生 することがある。図－5 は大台町久豆で発生した受け盤 をなす緑色岩・砂岩を基盤とする尾根のブロック崩壊事 例模式断面図であり, 尾根の表層が最大厚 $13 \mathrm{~m}$ 程度ク リープしていた。また，写真-4は同クリープ箇所で切 土時に発見された岩盤内の開口亀裂である。2004年の21

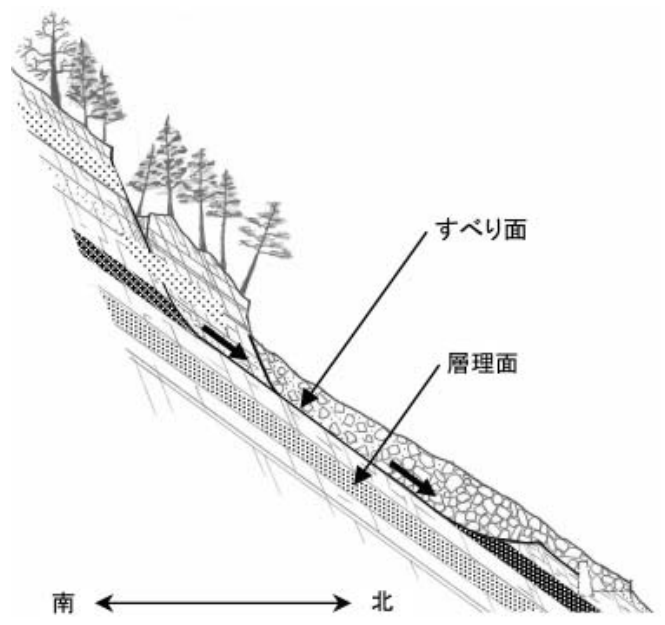

図一４秩父帯頁岩複合すべり模式図

Fig. 4 Schematic sketch of a complex slide of shale in the Chichibu Belt.

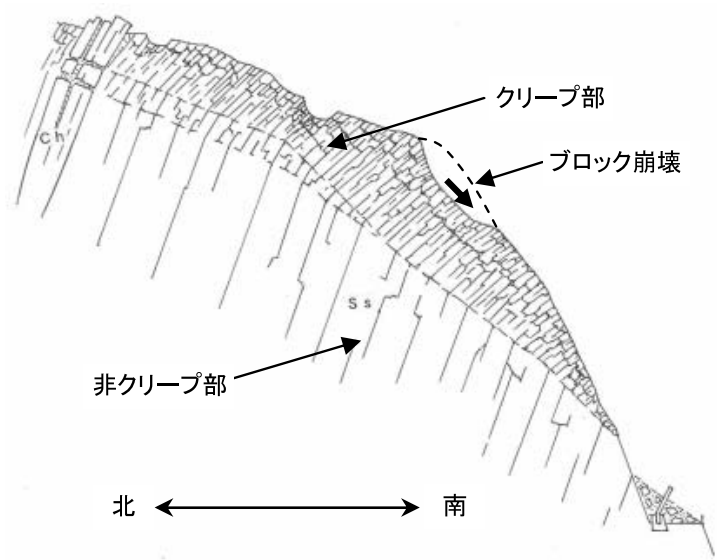

図ー5 秩父帯のクリープとブロック崩壊模式図

Fig. 5 Schematic sketch of a creep and a block failure in the Chichibu Belt.
号台風では層理面に対し受け盤となる南向き斜面で幅約 $70 \mathrm{~m} ，$ 長さ約 $110 \mathrm{~m}$ さびすべりが発生したが，2系統の 断層面をすべり面としていた。これ以外に，南向き北向 きを問わず多くの崩壊が発生した。この時の崩壊は大台 町島谷，春日谷など時間最大降水量が $100 \mathrm{~mm}$ 超えた 地域で多く発生した。その頻度について検討したが，三 波川帯との差はなかった。

\section{3 四万十帯の斜面破壊}

四万十帯は，白亜紀の付加体堆積物で，砂岩・泥岩を 主体とし，チャート・火砕岩などを挟在する。四万十带 は，主に秩父帯の南に带状に分布し，秩父带と同様，ほ ぼ東一西の走向を持ち北傾斜の層理面を持つものが多い。 三重に分布する四万十帯では層理面に沿った小規模な平 面すべり・複合すべりが発生することはあるが，筆者は 最近の約 15 年間，幅 $50 \mathrm{~m}$ 以上に㧍よぶ中規模以上の地す ベりは確認していない。しかし，地形的には幅 $200 \mathrm{~m}$ 超える凹状単丘型や多丘型地すべり地形が幾つか認めら れことから，過去には幾つかの大規模な地すべりが発生 した可能性が考えられる。図一 6 は南伊勢町で認められ た地すべり跡地の一例であり，写真－ 5 にその南側頭部 滑落崖と移動体を示す。

\section{4 熊野酸性岩類の斜面破壊}

熊野酸性岩類は花崗斑岩を主とし，流紋岩・凝灰岩を 伴う。花崗斑岩分布域の周縁部は柱状節理や板状節理の 発達したものが多い。花崗斑岩分布域の内，柱状節理と ともに水平の亀裂が発達した岩体が露頭している区域で は，地震時だけでなく平常時にも節理面から分離し大規 模落石を発生することがある。写真－6 は紀宝町で平常 時に発生した落石の事例である。2004年に発生した紀伊 半島沖地震（震度 4 程度）でも落石が発生しており, 今 後同等以上の地震時には落石が発生する可能性が大きい と考えられる。また，さらに風化し亀裂が発達した簓所 では，大規模なブロック崩壊を発生することがある。写 真 -7 は熊野市で豪雨を誘因として幅約 $30 \mathrm{~m}$ ，長さ約 30

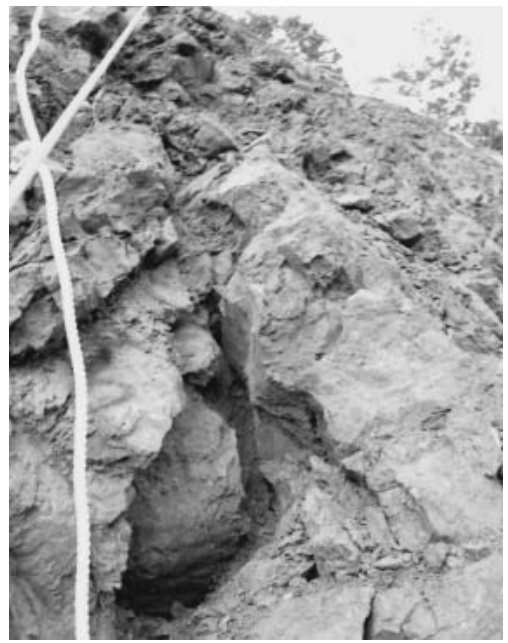

写真ー 4 クリープによる岩盤の開口亀裂（2004年）

Photo 4 Open crack made by creep. (2004) 
$\mathrm{m}$ にわたってブロック崩壊を発生した事例である。

\section{5 熊野層群の斜面破壊}

熊野層群は四万十帯を不整合に覆う第三紀中新世の堆 積物で，礫岩・砂岩・シルト岩・泥岩などからなる。熊 野層群の泥岩分布域にはいわゆる「棚田」を形成してい る場所が多数あり，これらの中には凹状多丘型地すべり

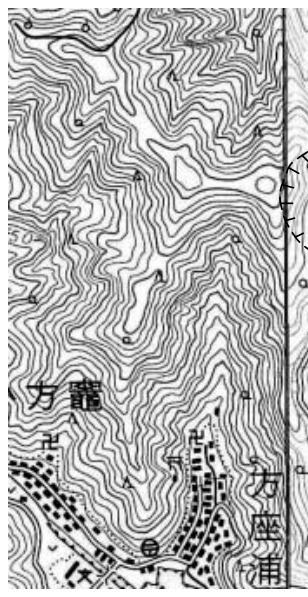

-6 四万十帯の地すべり地形

Fig. 6 Topographic features of a landslide in the Shimanto Belt.

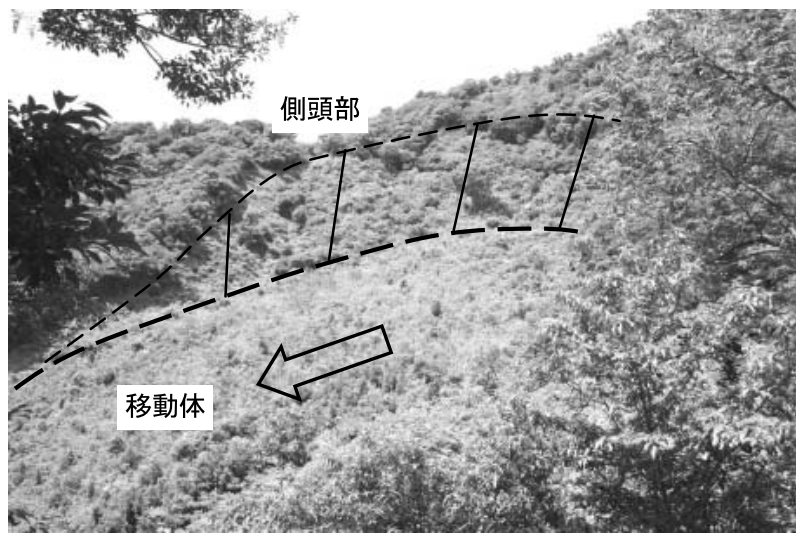

写真－ 5 図ー 6 箇所地すべり頭部（2004年）

Photo 5 Crown of the landslide shown in Fig. 6. (2004)

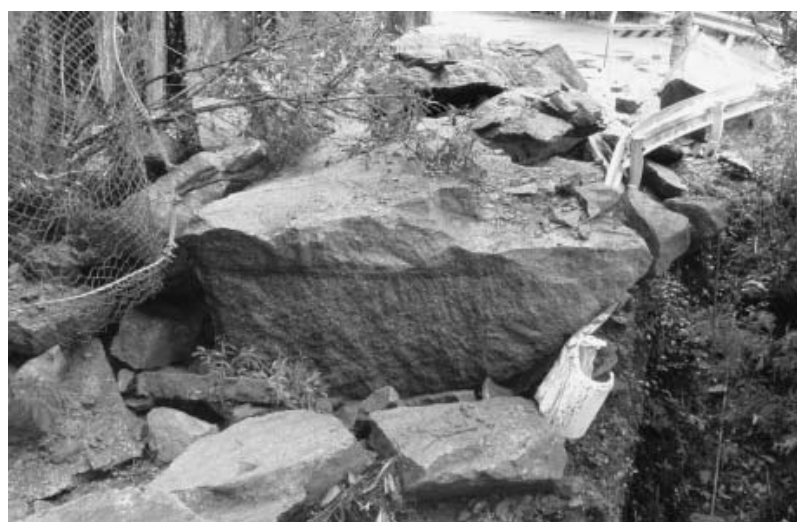

写真－6 熊野酸性岩類の大規模落石（2004年）

Photo 6 Large rock fall of the Kumano acidic rocks. (2004)
地となっているものがある。特に，泥岩・シルト岩を基 盤とし，流れ盤の層理面を持つ地域は，切土などの人為 的地形改変を誘因として，複合すべりが発生することが ある。紀州鉱山付近の基盤が熱水変質を受けている地区 では，まれに複合すべりを発生することがある。また， 風化が進行した箇所では受け盤，流れ盤を問わず比較的 大規模な地すべりを発生することがある。図 - 7 は御浜 町で発生した幅約 $170 \mathrm{~m}$ 長さ約 $170 \mathrm{~m}$ の複合すべりの模式 図であり，受け盤をなす風化砂岩・泥岩を移動土塊とし ていた。写真－8はその末端隆起現象である。急崖をな し比較的新鮮な岩盤が露頭する場所では，高角度亀裂を 分離面としてブロックトップリングを起こすことがある。 写真 -9 は熊野層群のCM級砂岩がブロックトップリン グを起こした事例である。

\section{6 領家帯の斜面破壊}

領家帯は花崗岩類と低圧高温変成作用による変成岩類 などからなり，中央構造線の北側に広く分布している。

一般に三重の領家帯の花崗岩類は深層まで風化が進行し, 厚くマサ化している。領家帯花崗岩類，特に古期領家花 崗岩類の城立トナール岩と，新期領家花崗岩類の加太花 崗岩，阿保花崗岩起源のマサは，複合すべりを発生する ことが非常に多い。過去の発生例を見ると風化境界面を すべり面としているものが多い。また，頭部にアプライ トが貫入していた例が 2 例あり，図 -8 はアプライト貫 入面を頭部として発生した伊賀市の複合すべりの模式図 である。阿保花崗岩は黒雲母が集積している箇所がある。

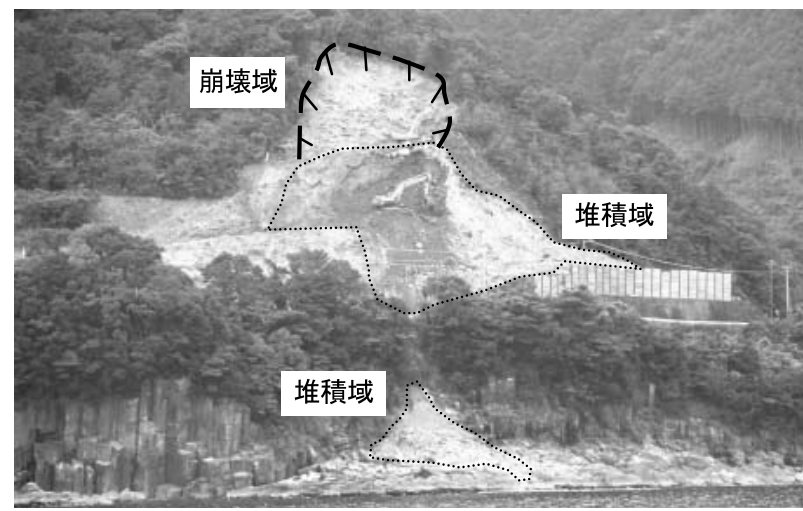

写真－ 7 熊野酸性岩類のブロック崩壊（1998年）

Photo 7 Block failure of the Kumano acidic rocks (1998)

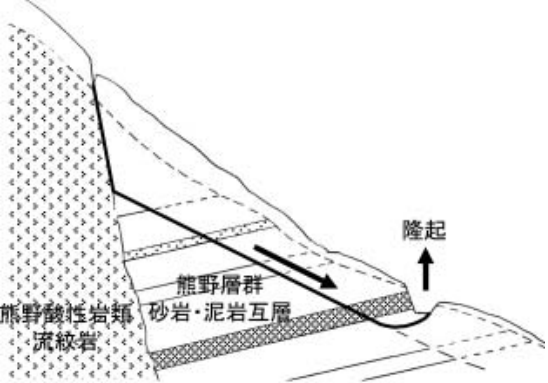

図ー 7 熊野層群複合すべり模式図

Fig. 6 Schematic sketch of a complex slide in the Kumano Group. 
黒雲母が集積したマサで切土を行うと，法表層が大きく 膨張し，地盤を緩めるため，崩壊発生の素因となる可能 性が考えられる。写真－10は伊賀市において黒雲母の多 いマサが黒雲母の少ないマサより $2 \mathrm{~cm} ３ \mathrm{~cm}$ 大きく膨 張したため，断層を境として相対的に斜め上方に変位し た事例である。

\section{7 美濃帯の斜面破壊}

美濃帯は, 中生代三畳紀〜ジュラ紀の堆積物で砂岩・ 頁岩・石灰岩などからなり，北部に分布する。岐阜では， 揖斐川町東横山地区をはじめ，美濃帯を基盤とする地区 で幅数十メートルを超える大規模な地すべりやブロック 崩壊が2003年と2006年に発生している。しかし，三重の 美濃带では，最近の約15年間に発生した大規模な斜面破 壊は，複合すべりの 1 件と少ない。図－9 は亀山市で発 生した $60^{\circ} \sim 70^{\circ}$ の高角度受け盤をなす切土法面における 複合すべりの模式図であり，写真－11は同地すべり末端 の押し出し状況である。当箇所の岩相は粘板岩を主体と し薄い砂岩を挟在している。頭部に断層地形が認められ ることから，断層が 1 つの素因となっているものと考え られる。

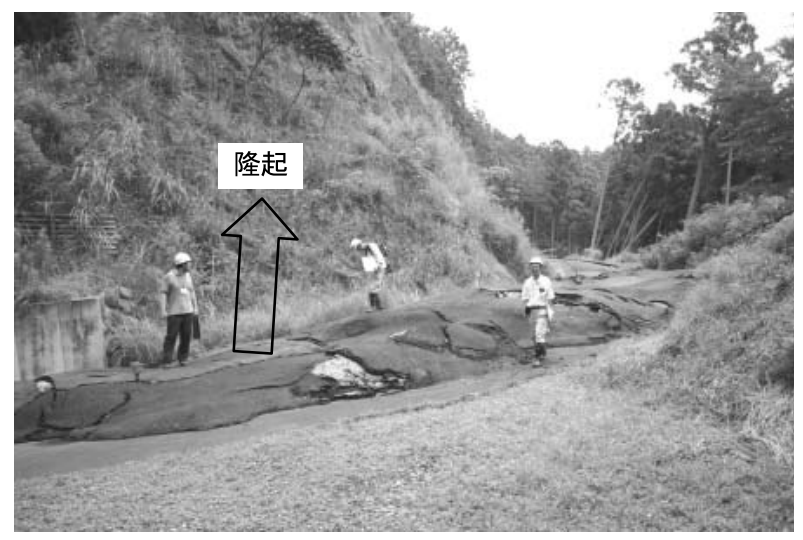

写真一8 熊野層群で発生した複合すべりの末端隆起(2007年) Photo 8 Upheaval of the toe of complex slide of the Kumano Group (2007)

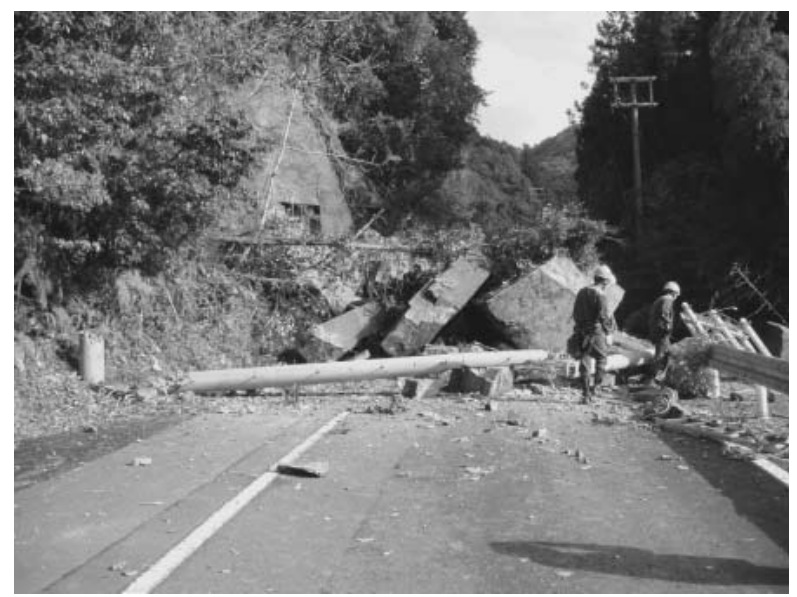

写真一 9 熊野層群のブロックトップリング（2005年） Photo 9 Block toppling in the Kumano Group (2005)

\section{8 室生火山岩類の斜面破壊}

室生火山岩類は，第三紀中新世に噴出した火砕流堆積 物で，流紋岩質溶結凝灰岩からなり，三重から奈良にか けて分布する。溶結凝灰岩はほぼ垂直な柱状節理をなす 部分を主体とし，節理のあまり発達していない部分（こ の部分も溶結している）を薄層で挟む。また，柱状節理 をなす岩体では，柱状節理面とは別にN30／E30S系の低 角度の節理面がところどころで見られる。このため，ブ ロックトップリングやバックリングにより柱状岩が落下 することがある。現在までの調査では $1.5 \times 1.5 \times 3.0 \mathrm{~m}$ 程度の大きな柱状岩の落下も確認されている。このよう

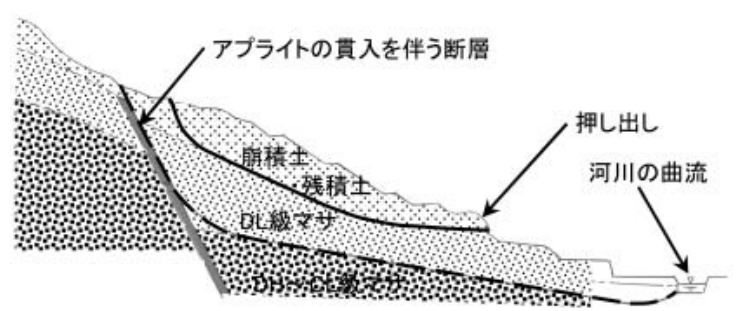

図－8 風化阿保花崗岩の複合すべり模式図

Fig. 8 Schematic sketch of a complex slide in the weathered Ao granite

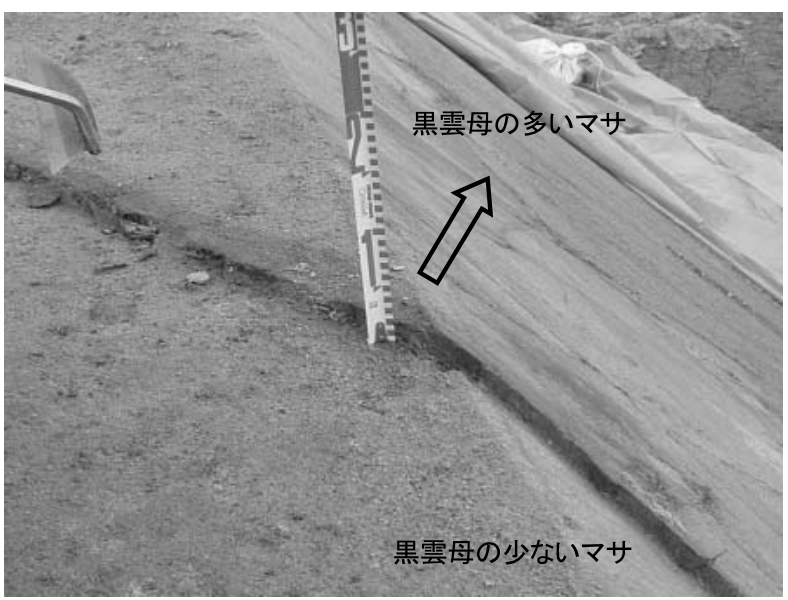

写真一10 マサの差別的膨張による地表面のずれ（2004年）

Photo10 Dislocation of the ground surface due to the differential expansion of the decomposed granite. (2004)

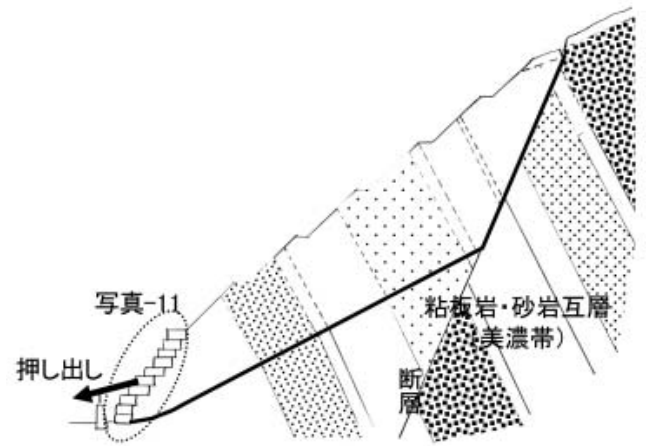

図－9 美濃帯複合すべり模式図

Fig. 9 The complex slide mimetic diagram of the Mino Belt 
な落石は柱状節理の開口はもとより，支持部の欠如や低 角度節理面の劣化，荷重によって形成された圧縮亀裂面 の開口によって平常時においても発生することがある。 また，水戸・相澤ら（2002）は開口節理面に沿った地下 水が素因の 1 つとなっていることを解明している。溶結 凝灰岩に扔ける柱状節理面の開口は，物理的風化だけで なく生物風化，特に木根の進入によるものが著しい。図 - 10は名張市の室生火山岩類柱状節理部におけるバック リングの模式図である。また，2004年に発生した紀伊半 島沖地震（震度 3 程度）でも落石が発生しており, 今後, 同等の以上の地震時には落石が発生する可能性が大きい と考えられる。

\section{9 一志層群・鈴鹿層群の斜面破壊}

一志層群，鈴鹿層群は，第三紀中新世の堆積物で，主 に泥岩・砂岩・礫岩などからなる。一志層群は一般に $35^{\circ}$ 以下の傾斜の層理面を持っている。一志層群，鈴鹿層群 の内，泥岩を主体とする層では，流れ盤の斜面・法面で 複合すべりや平面すべりを発生する場合がある。特に， 一志層群の泥岩砂岩互層では，流れ盤の層理面を主なす

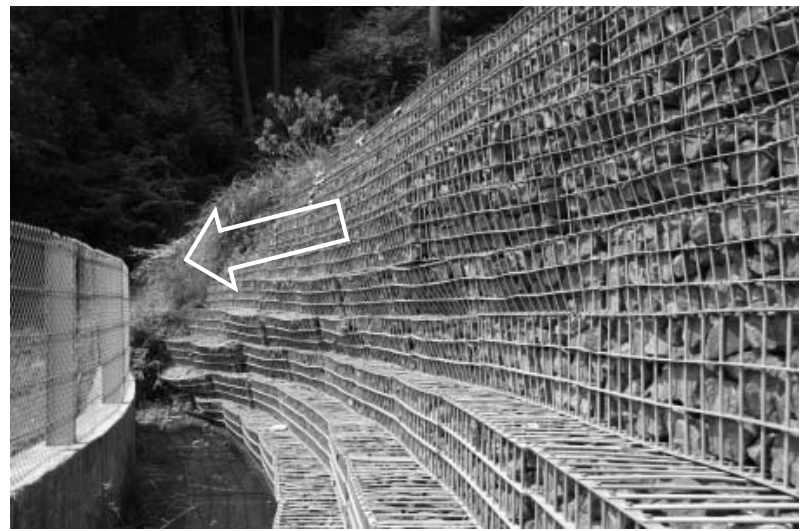

写真－11＼cjkstart地すべり末端の押し出し（2005年）

Photo11 Extrusion of a landslide toe. (2005)

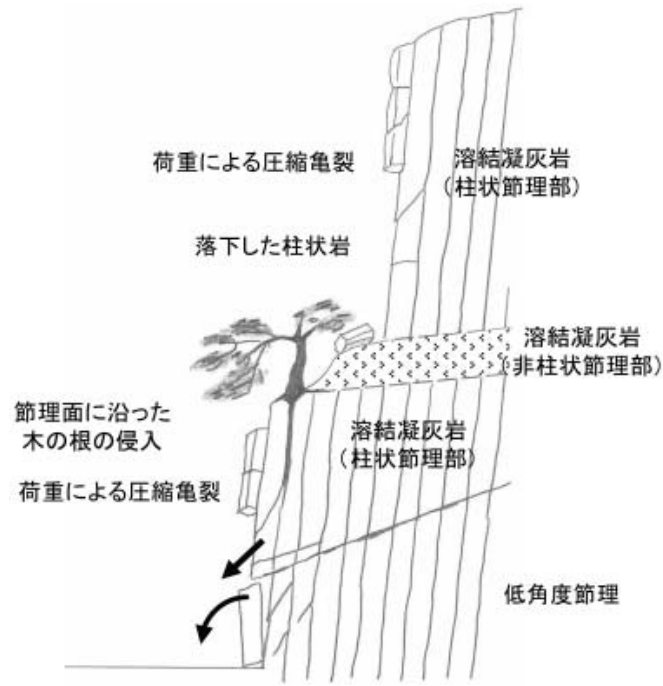

図－10＼cjkstart室生火山岩類バックリング模式図

Fig. 10 Schematic sketch of the buckling of the Murou volcanic rocks
ベり面として平面すべりや複合すべりが発生することが 多い。しかし，受け盤をなす斜面で発生した地すべりは 報告されていない。写真-12は松阪市において，約 $35^{\circ}$ の高角度層理面箇所で発生した平面すべりである。

\subsection{0 古琵琶湖層群・東海層群の斜面破壊}

古琵琶湖層群，東海（奄芸）層群は，第三紀鮮新世〜 第四紀更新世の湖沼堆積物であり，低固結の粘土・シル ト・砂を主体とする。一般には $10^{\circ}$ 以下の傾斜の層理面 を持つが，大規模な活断層の近傍では，断層運動により 引きずられ $30^{\circ}$ からほほ鉛直の高角度層理面を示すこと がある。古琵琶湖層群，東海層群は低固結であるため, 地下水が存在している所では, 切土などの人為的地形改 変を誘因として複合すべりを発生することがある。古琵 琶湖層群は, 層理面の傾斜が 5 程度でも, 層理面に沿っ て複合すべりが発生した事例が 2 箇所確認されている。 図－11は伊賀市において固結粘土・シルト互層からなる 古琵琶湖層群で発生した地すべりの模式図で，写真 -13 は同地すべり末端の押し出しと隆起の状況である。また， 断層付近で高角度の層理面を持つ東海層群は切土を誘因 としてたわみ性トップリングを発生することがある。図 - 12は一志断層 (活断層) 東方約 $80 \mathrm{~m}$ の亀山市関町にお いて，ほぼ鉛直の層理面を持つシルト・粘土互層の東海 層群で，切土を実施したために発生したトップリングの 模式図であり，写真一14は同地区において発生したトッ プリングによる亀裂である。

\section{4. 終わりに}

三重で過去約15年にわたって発生した斜面の変形や破

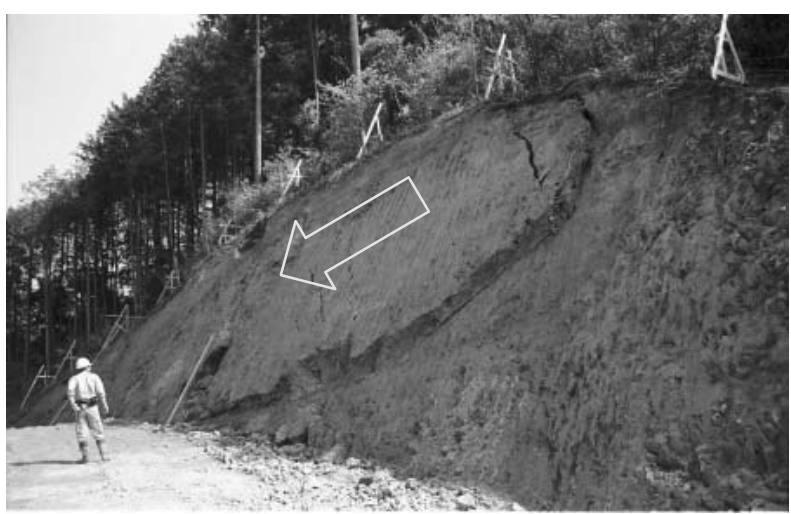

写真ー12 層理面に沿った一志層群の平面すべり（1999年） Photo12 Landslide with a planar sliding surface along a bedding plane in the Ichishi Group. (1999)

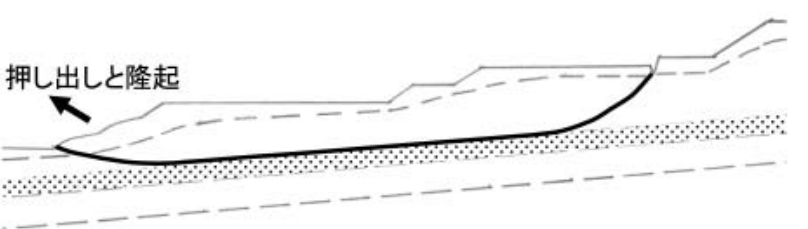

図ー11 古琵琶湖層群の複合すべり模式図

Fig. 11 Schematic sketch of a complex slide of the Kobiwako Group 


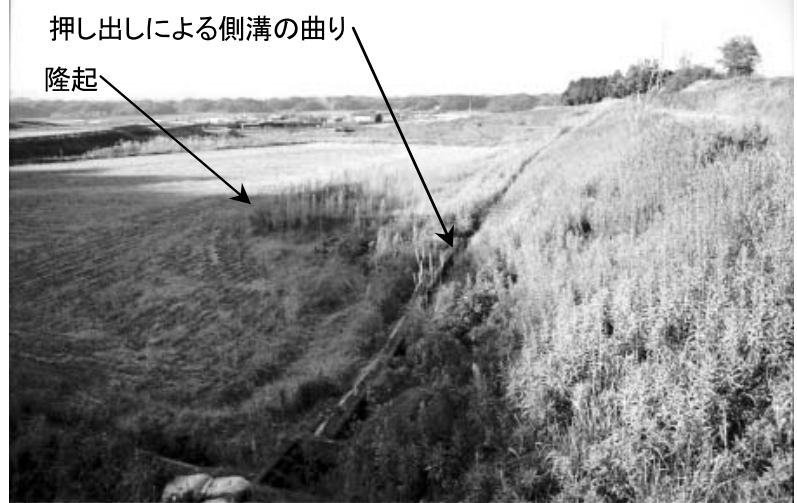

写真一13 地すべり末端の押し出しと隆起（2000年） Photo13 Extrusion and upheaval of a landslide toe. (2000)

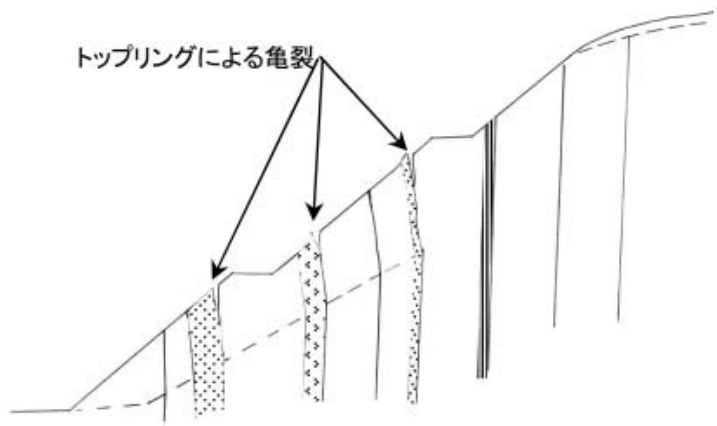

図ー12 東海層群のトップリング模式図

Fig. 12 Schematic sketch of a toppling in the Tokai Group.

壊形態の特徵を各地質帯の岩相ごとに検討した。その結 果，堆積岩や結晶片岩を基盤とする斜面・法面では流れ 盤をなす場合，層理面や片理面に規制された地すべりが 多く発生し，受け盤をなす場合はクリープが発生するこ とが判明した。この結果は，藤田・板垣（1976）の統計 結果とも一致することが明らかとなった。全国的にはマ サを移動土塊とする地すべりは比較的少ないが，三重で は領家帯の花崗岩類起源のマサで地すべりを発生するこ とが多かった。柱状節理が発達した熊野酸性岩類の花崗 斑岩や室生火山岩類の流紋岩質熔結凝灰岩は，地震時た けでなく平常時にも大規模落石が発生することが判明し た。第三紀中新世の堆積物である, 熊野層群, 一志層群, 鈴鹿層群を基盤とする地区では，流れ盤をなす場所や棚 田地形をなす場所，風化の進行した場所で複合すべりや 平面すべりが発生しやすいことが分かった。また，紀州 鉱山付近では熱水変質を受けている場所で複合すべりが 発生する場合があった。第三系鮮新統～第四系更統の低 固結粘土・シルトからなる古琵琶湖層群や東海層群は, 層理面が 5 程度の緩勾配でも複合すべりを発生する場 合があることが明らかとなった。東海層群は活断層付近 において層理面が大きく傾斜している場合があり，この ような場所で切土を行うと，トップリングを発生する場 合があった。

以上のように三重では，岩相と斜面の変形や破壊形態

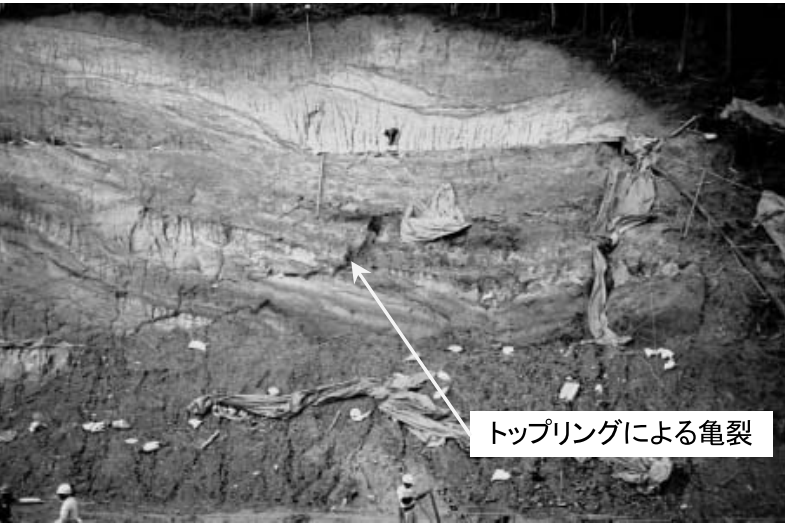

写真一14 一志断層近傍で発生したトップリング（1994年） Photo14 Toppling occurred near the Ichishi fault. (1994)

に密接な関係にあることが判明した。この結果は，西南 日本内帯・外帯をはじめとする同様の地質が分布する地 域で共通する部分が多いものと推測される。しかし，同 様の地質から構成される紀伊半島西部，四国などとは地 すべり規模など異なる要素もあり，源岩の構成鉱物など により地すべり発生のしやすさや地すべり特性も異なる 可能性があるものと考えられる。このため，今後は岩相 だけでなく構成鉱物の差などの詳細な地質的差異はもち ろんのこと，年間降水量や地盤隆起量など地質以外の要 因も加味して，同様の地質を基盤とする他地域と差異が 出る原因について研究を発展してゆく必要があるものと 考えている。

\section{謝 辞}

本研究を進めるにあたり，坂幸恭早稲田大学元教授に は三重の地質について適切な助言をいただいた。深く感 謝いたします。

\section{参考文献}

1 ）谷口敏雄（1963）：地すべり調查と対策，山海堂, p. 13 .

2 ）藤田寿雄・板垣治（1976）：土木研究所資料1121号，地すべり 実態統計〔その 2] 建設省土木研究所, p. 11 .

3 ）渡正亮 (1986)：斜面災害の機構と対策，山海堂，pp. 6-9

4 ）奥園誠之ほか（1994）：岩盤斜面の安定解析と計測，土木学会， pp. $3-7$

5 ）川辺孝幸・高橋裕平・小村良二・田口雄作（1996）：5 万分の 1 図幅, 上野地域の地質, 地質調査所, pp. 15-44

6 ）西岡芳晴 - 尾崎正紀 - 山元孝広・川辺孝幸 (1998)：5 万分の 1 図幅，名張地域の地質，地質調査所，pp. 19-50，付図

7 ）坂幸恭ほか (1999）：志摩半島の秩父帯と黒瀬川帯・日本地質 学会見学旅行案内書, pp. $163-168$

8 ）坂幸恭・綿谷好修（2002）：三重県の地盤，地質と調査，社)全 国地質調查業協会連合会, pp. $35-41$

9 ）水戸義忠・相澤泰造・平山拓哉（2002）：数量化理論を用いた 溶結凝灰岩分布域に扔ける落石危険度評価, 地すべり，Vol. 39 No. 1 , pp. $95-103$

10）相澤泰造（2005）：三重の地質と斜面リスクマネジメント，(財) 三重県建設技術センター, pp. 10-11

11）相澤泰造（2007）：三重に抢ける岩相と斜面破壊形態の特徵, 第46回日本地すべり学会研究発表会講演集, pp. 1- 4

（原稿受付2008年 5 月 26日，原稿受理2008年11月10日） 